\section{参考文献}

1) 足立 晋, 浮田昌昭, 石田進一郎, 他：量子計数型X線撮 影法の開発。島津評論, 49(3), 185-189, (1992).

2) 石田進一郎, 浮田昌昭, 佐藤敏幸, 他：量子計数型X線撮 影䒾置の開発。島津評論，51(1)，5-9，(1994)。

3）木村和彦, 采氏英一郎, 山崎克人, 他：量子計数型X線撮 影法による肺癌診断有用性，肺癌，33(5)，720，(1993)。
4) 木村和彦, 河野通雄, 系氏英一郎, 他：量子計数型X線撮 影法による肺野結節影の検出能の評価。日本医放会誌, 55 (5), 343-344, (1995).

5) 木村和彦, 系氏英一郎, 山崎克人, 他：新しいディジタル 胸部 X線撮影法の画像評価. 日本医放会誌, $56(2)$, S 160 , (1996).

\title{
2. 画像変換－画質改善処理とその唣床評価一
}

\section{Ir:110 \\ 木戸尚治 \\ 大阪府立成人病センタ一放射線診価科}

\section{1.はじめに}

画像変換とは入力された画像を出力する際に，人間 の視覚機能にあわせて見やすい画像にしたり補正をし たりする处理をいう。一般的には，階調処理や，周波 数処理といった画質改善処理や画像の拡大・縮小・回 転などの補正処理，あるいは後で述べるエネルギーサ ブトラクション処理のような複数の画像から出力画像 を再構成する処理などがある。このような処理は，現 在ではコンピュー夕を用いて行うため, 画像変換を行 うためには，FCR (Fuji computed radiography)をはじ めとしたDR (digital radiography) システムがスクリー ン/フィルム・システムに比べて有利である。

FCRは，富士写真フィルムにより開発されたディジ タルX線画像システムであり, 従来のスクリーン/フィ ルムに代えてX線画像情報記録能力を持つ輝尽蛍光体 を塗布したイメージング・プレートをセンサーとして 用いている、イメージング・プレートにX線が照射さ 机るとイメージング・プレートの輝尽蛍光物質内にX 線情報が記録され，次にこれを読み取り装置のレー ザ・ビームでスキャンしてその情報を光信号として読 み出す。またイメージング・プレートは消去光で情報 を消して繰り返して利用することが可能である (Fig.1).FCRシステムではこの光信号を電気信号に変 換して，画像処理したのち，モニタに表示したり，レ 一ザイメージャを用いてフィルムに焼き付けて画像化 している．また画像データは磁気ディスクや光ディス ク等に記録し保存することが可能である。

FCRの利点としては, スクリーンノフィムに 比べて広いダイナミックレンジを持つこと，ディ ジタル画像として画像処理が容易であること, 保 存・伝送に適していることがあげられている。ま たスクリーン/フィルムに比べて患者への被曝線 量の低減化できることも利点としてがあげられて いたが，これは画質が少化する，一方で欠点は， 空間解像度がスクリーンノフィムに比べて劣る ことや表示画像サイズの小さいことが問題とされ てきたが，こ机は最新のFCR 9000では改善され ている。ここではFCRの持つ特性を生かしたダイ ナミックレンジ・コントロール処理と, 粒状性改 善エネルギーサブトラクション処理について解説 し，あわせてその評価について述べる。

\section{2. 方法と結果}

\section{2-1 ダイナミックレンジ・コントロール処理}

胸部単純X線写真では，ダイナミックレンジが限ら 机ているため, 肺野部と縦隔部で適切な濃度を一枚の フィルム上で得ることは困難である. FCRは広いダイ ナミックレンジを持つが，これを一枚のフィルム上の 限られた濃度範囲に表現することはやはり困難であ り，一枚のハードコピーに肺野用の従来画像と縦隔用 の周波数処理画像の二種類を組にして通常は表示す る。ダイナミックレンジ・コントロール処理 (dynamic range control processing)は，非鮮鋭マスクを用 いて平滑化した画像を原画像に対して重み付け加算す ることによりなされる(Fig.2)。この手法は，国立がん センターの阿南らの「胸部用自己補償ディジタルフィ

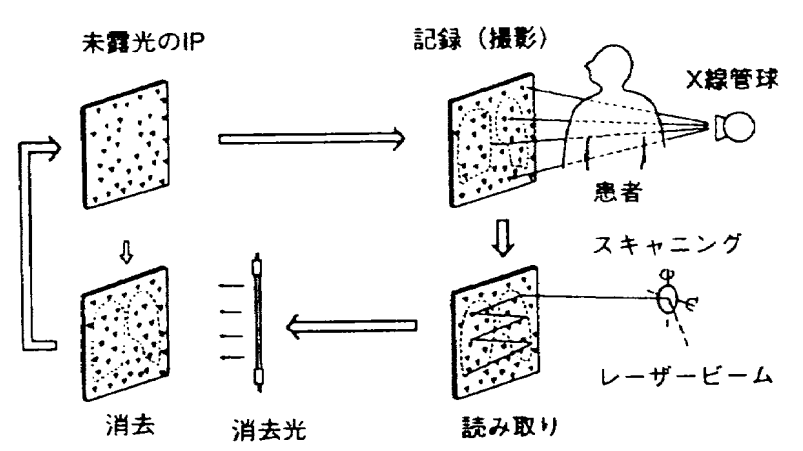

Fig. 1 Principle of imaging plate (IP).

1997 年 4 月

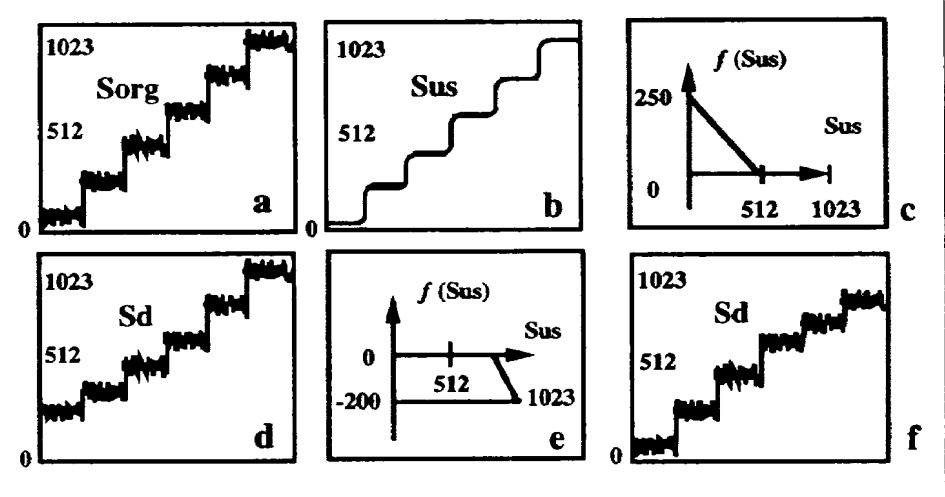

Fig. 2 Principle of dynamic range control processing 
ルタ」を参考にして一般化したものである．Fig.2の (a) は横軸がX線写真上に扔ける位置を示し，縦軸がそ の濃度值を表す。階段状の変化は肺野や縦隔部等の大 きな解剖学的な構造物に対応し, 各階段状の信号にお ける細かな变化は血管影や間質性陰影等に対応する。

(b)に示されるような平滑化処理

$$
\mathrm{S}_{\mathrm{us}}=\sum \mathrm{S}_{\mathrm{org}} / \mathrm{M}^{2}
$$

を行うと，細かな陰影変化は平滑化される。この信号 Sus (c) に示す関数で変換して，原画像Sorgに加算する 処理を行うと $(\mathrm{d})$ で示されるようなダイナミックレン ジ・コントロール処理画像 $\mathrm{S}_{\mathrm{d}}$ 节得られる。

$$
\mathrm{S}_{\mathrm{d}}=\mathrm{S}_{\text {org }}+f\left(\mathrm{~S}_{\mathrm{us}}\right)
$$

(d)の画像では，低濃度域が持ち上げられ，全体の ダイナミックレンジは圧縮されている。 しかし各階段 上に存在する細かな信号は保存されており，この点が 階調処理とは異なっている。また(c)の代わりに(e)の ような関数を用いると，(f) で示されるような高濃度 域が扔さえられたダイナミックレンジ・コントロール 処理画像を得ることもできる。このように，ダイナミ ックレンジ・コントロール処理により, 縦隔部の濃度 コントラストは改善するが, 肺野部はできるだけオリ ジナルのコントラストの状態を保った画像を得ること ができる (Fig.3).

胸部単純X線画像におけるダイナミックレンジ・コ ントロール処理の有効性について 3 人の放射線科医が ダイナミックレンジ・コントロール処理画像, 高周波 強調画像とオリジナルのスクリーン/フィルム画像に 近いスタンダード画像を用いて視覚的な評価を行っ

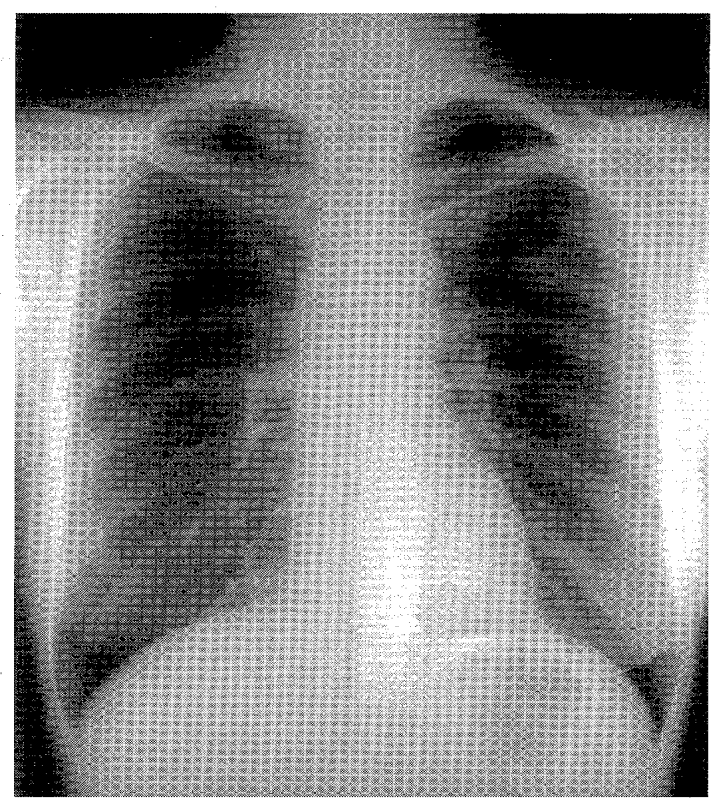

Fig. 3 Dynamic range control processed image, 55-year-old woman with adenocarcinoma. A faint pulmonary nodule is located in the left upper lung zone.
た。その結果，縦隔の正常構造抢よび，肺野の網状・ 粒状陰影, 肺腫瘤陰影, 骨異常陰影ではダイナミック レンジ・コントロール処理画像の方がダイナミックレ ンジ・コントロール㚮理を行っていないスタンダード 画像よりも描出能が優れていることが示された。また ダイナミックレンジ・コントロール処理画像は気管の 描出能に関しては高周波強調画像に比べて劣っていた が, 胸椎，肺腫瘤陰影の描出能に関しては高周波強調 画像よりも優れていた。さらに高周波強調画像とダイ ナミックレンジ・コントロール処理画像は縦隔の描出 能に関しては同様に優れているが，高周波強調画像で は肺野㓌影が強調されるため, 肺野の微細病変の診断 は困難であると考えられた1)。またこのダイナミック レンジ・コントロール処理高精細ライフサイズ画像 (空間解像度 $0.1 \mathrm{~mm}, 4000 \times 5000$ 面素) とスクリーン/フ イルム画像の比較を微細な間質性病変の症例を用いて 12 人の放射線科医が読影実験を行った。 ROC解析の 結果からはダイナミックレンジ・コントロール処理高 精細ライフサイズ画像とスクリーン/フィルム画像の 診断能に有意差は認められなかった22.このようにし てダイナミックレンジ・コントロール処理画像では, 縦隔部ではスクリーン/フィルム画像に比べて描出能 に優れて㧍り，しかも肺野部はスクリーンハイルム 画像とほぼ同等な描出能が得られた。また，ダイナミ ックレンジ・コントロール処理高精細ライフサイズ画 像ではスクリーン/フィルム画像と同等な診断能が得 られた。

\section{2-2 粒状性改善エネルギーサブトラクション処理}

エネルギーサブトラクション処理は骨や軟部組織な どでX線吸収特性が異なることを利用して，2 種類の 画像から荷重演算法により骨陰影を消去したり逆に骨 陰影のみの画像を作成したりする画像処理法である (Fig.4).エネルギーサブトラクション法の撮像の仕方 には，2つの異なるX線エネルギーを照射する 2 回曝 射法もあるが, 通常よく用いられるのは 1 回曝射法で ある. 1 回曝射法ではFig.5のように，2枚のイメージ ング・プレートの間に銅などのフィルタをはさんでX 線を照射して，この 2 枚のイメージング・プレートか

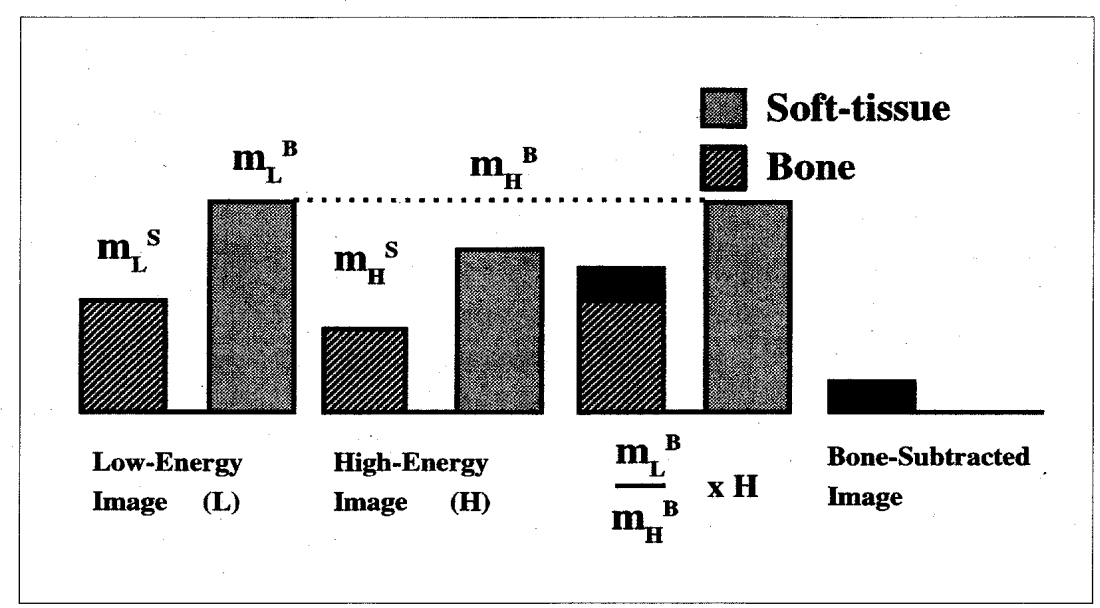

Fig. 4 Principle of the single-exposure dual-energy subtraction method. 
ら得られた低压高圧の2 種類の画像から骨部消去画像 と軟部組織消去画像を作成する。特に骨部消去画像は 肋骨陰影が消去されているので，肺野での結節陰影が 見やすくなり見落としが減少し，肺癌検診など!有用 である.1回曝射法によるエネルギーサブトラクショ ン法は，撮影装置が簡単であり，体動によるアーチフ アクトがないという利点があるが，通常撮影X線量で は画像の粒状性が良くないという久点がある。

粒状性を改善したエネルギーサブトラクションのア ルゴリズムの概略をFig.6に示す3．従来のエネルギー サブトラクション処理法ではフィルタの前後の 2 枚の イメージング・プレートから得ら机た画像をそのまま 用いて骨部消去画像と軟部組織消去画像を得ていた が，新しい方法では第 1 段階として軟部組織消去画像 のほかに粒状性を改善した重み付き可算平均画像をつ くる.この画像はサブトラクション像の粒状性を改善 していくプロセスにおける基隼画像となる。このよう な重み付き平均画像 $(\mathrm{A}(\mathrm{x}, \mathrm{y}))$ は, 低エネルギー画像の ノイズを $\mathrm{NL}_{\mathrm{L}}$ 高エネルギー画像のノイズを $\mathrm{N}_{\mathrm{H}}$ ノした とき, 次のような式で求めら妃る。

$$
\begin{aligned}
& \mathrm{A}(\mathrm{x}, \mathrm{y})=\alpha \times \mathrm{H}(\mathrm{x}, \mathrm{y})+\beta \times \mathrm{L}(\mathrm{x}, \mathrm{y}) \\
& \alpha=\left(\mathrm{N}_{\mathrm{L}}\right)^{2} /\left(\left(\mathrm{N}_{\mathrm{H}}\right)^{2}+\left(\mathrm{N}_{\mathrm{L}}\right)^{2}\right), \quad \beta=\left(\mathrm{N}_{\mathrm{H}}\right)^{2} /\left(\left(\mathrm{N}_{\mathrm{H}}\right)^{2}+\left(\mathrm{N}_{\mathrm{L}}\right)^{2}\right)
\end{aligned}
$$

ここで $\alpha$ とははれ防高エネルギー画像と低エネル ギー画像に対する重み係数である。第 2 段階ではさこの 重み付き平均画像と従来法の骨部消去画像を用いて, 軟部組織消去画像 $(\mathrm{Bn}(\mathrm{x}, \mathrm{y}))$ を作る。

$$
\mathrm{Bn}(\mathrm{x}, \mathrm{y})=\mathrm{A}(\mathrm{x}, \mathrm{y})-\overline{\mathrm{S}(\mathrm{x}, \mathrm{y})}
$$

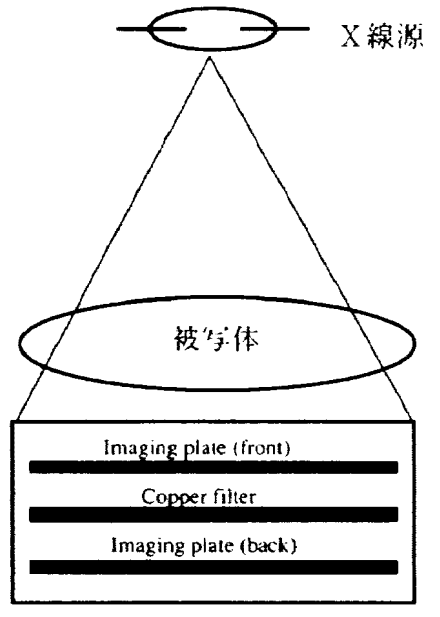

カセッテ

Fig. 5 Schema of $x$-ray detection system of the single-exposure dual-energy subtraction method. A copper filter $(0.8 \mathrm{~mm}$ thick) is sandwiched between two imaging plates in the cassette.
第 3 段階では，この軟部組織消去画像 $(\mathrm{Bn}(\mathrm{x}, \mathrm{y}))$ と重 み付き平均画像 $(\mathrm{A}(\mathrm{x}, \mathrm{y}))$ 加骨部消去画像 $(\operatorname{Sn}(\mathrm{x}, \mathrm{y}))$ を作成する。

$$
\operatorname{Sn}(x, y)=A(x, y)-\overline{\operatorname{Bn}(x, y)}
$$

この中間過程の平滑化画像を作るときに，骨部信号で は骨のエッジに高周波成分を持つことに着目して，エ ッジを劣化させることなく平滑化を行うエッジ保存平 滑化処理を行っている。このようなプロセスにより粒 状性の改善がみられるが，さらにフィルタのパラメー 夕を少しずつ変えながら䆆り返し処理を行うと, より 粒状性の改善されたサブトラクション画像を得ること ができる(Fig.7)。

粒状性を改善したエネルギーサブトラクション画像 の評価に関して述べる。最初にナイロン製の模擬結節 を付加した胸部ファントム画像を用いて10人の放射線 科医が参加して読影実験を行った。この結果では，胸 部単純X線写真のみを用いて読影した場合より，胸部 単純X線写真とエネルギーサブトラクション画像(骨 部消去画像)の両方を用いて読影した場合の方が検出 能力が高いことが示された。さらに従来画像より は，粒状性を改善した画像とともに読影した方がよ り検出能が高まることも示された4)。また肺に複数 の結節を持つ臨床例を用いて 14 人の放射線科医が参 加した読影実験も行った。この結果は, AFROC (Alternative free-responce receiver operating characteristic）解析により評価した。結果は模擬結節の場合 と同様に，胸部単純X線写真のみを用いて読影した場 合より，胸部単純X線与真とエネルギーサブトラクシ ヨン画像(骨部消去画像)の両方を用いて読影した場合 の方が検出能力が高く，また従来画像よりは，粒状性 を改善した画像とともに読影した力がより検出能が高 まることが示されだ。この粒状性を改善したエネル ギーサブトラクション処理機構を組み込んだFCR 9501 ESが実用化されている。

\section{3. 結 的}

CT PMRI等の画像診断法の進歩にも関わらず，胸

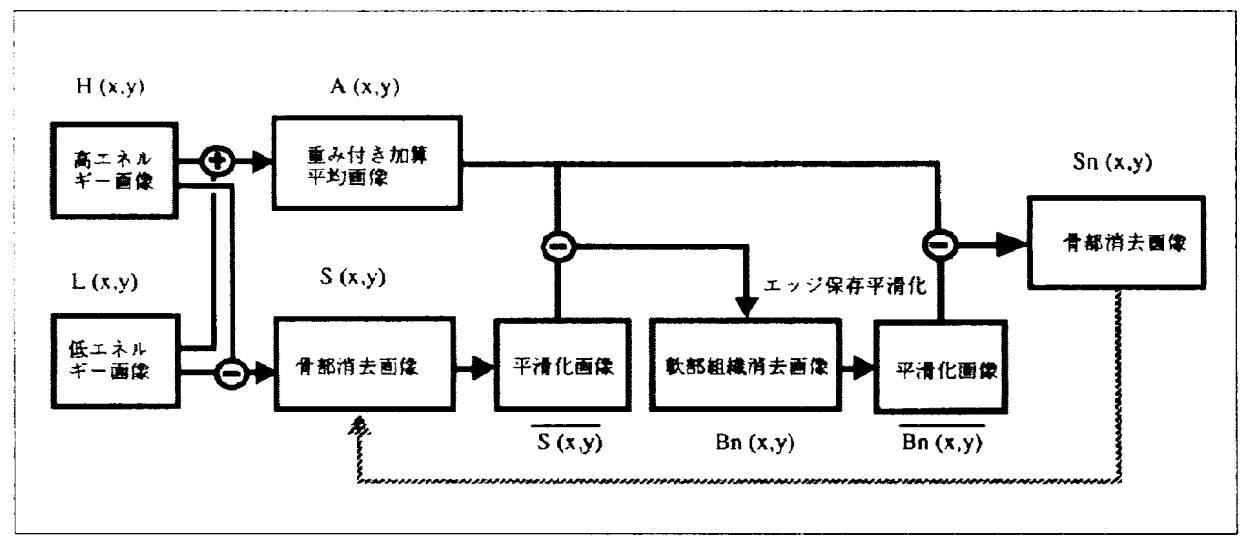

Fig. 6 Overall schema of the noise reduction algorithm of the single-exposure dualenergy subtraction method.

1997 年 4 月 


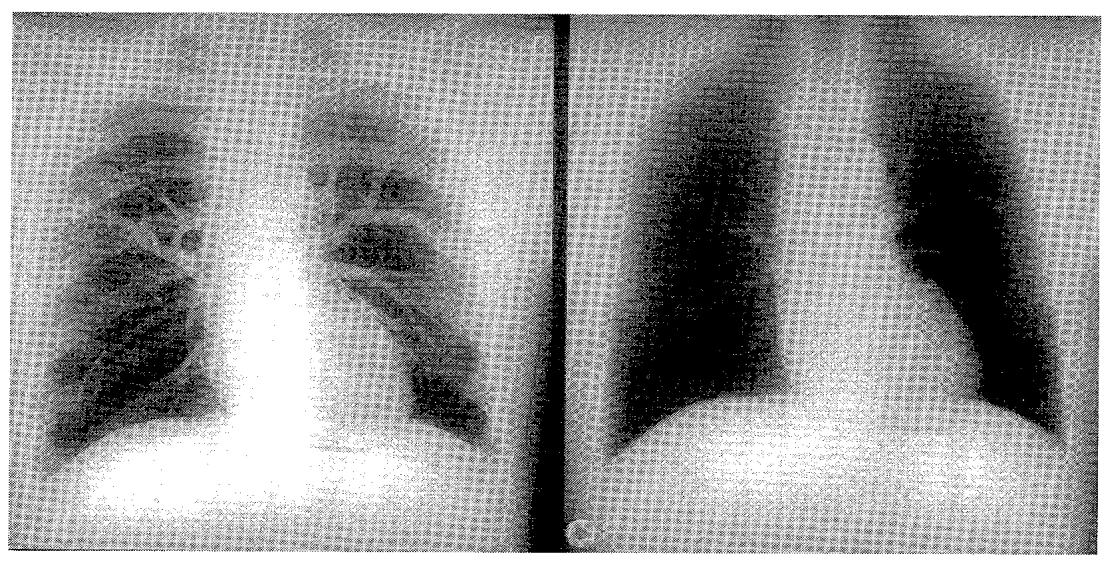

Fig. 7 Images of the chest phantom with a nylon nodule in the left upper lung zone. Left image is an original image and right image is a bone-subtracted image.
部単純X線写真の重要性は変わらず, 胸部 疾患のスクリーニングとして重要な位置 を占めている．検查にかかる費用や時間 等を考慮すれば, 第 1 選択はやはり胸部単 純X線写真であり，これで異常が疑われる 場合にCT検査を施行するというのが妥当 である.FCRの登場により胸部単純X線写 真の領域においてもディジタル画像の利 用が一般的になりつつある.FCRでは画 像がディジタルであるという特性を生か して,さまざまな画像変換が可能であ る.ダイナミックレンジ・コントロール 処理や粒状性改善エネルギーサブトラク ション処理のような画像変換処理は, 従 来のスクリーン/フィルム画像の持つ情報 に加えてさらに診断に有用な情報を放射 線科医に提供すると考えられる。

\section{参考文献}

1) Ikezoe J, Takeuchi N, Kido S, et al.: Dynamic range control processing of digital chest images. Acta. Radiol., 37, 107115, (1996).

2) Ikezoe J, Kohno N, Takeuchi N, et al.: Interpretation of subtle interstitial chest abnormalities: conventional radiography versus high-resolution storage phosphor radiography. Radiology, 197 (P), 340-341

3) Ito W, Shimura K, Nakajima N, et al.: Improvement of detection in computed radiography by new single-exposure dual- energy subtraction. Proc. SPIE, 1652, 386-396, (1992).

4) Kido S, Ikezoe J, Naito $H$, et al.: Single-exposure dual-energy chest images with computed radiography: evaluation with simulated nodules. Invest Radiol, 28, 482-487, (1993).

5) Kido S, Ikezoe J, Naito H, et al.: Clinical evaluation of pulmonary nodules with single-exposure dual-energy subtraction chest radiography with an iterative noise-reduction algorithm. Radiology, 194 (2), 407-412, (1995).

\section{3. 画像計測・理解-CADの臨床導入一}

\section{1. はじめに}

近年のディジタル画像技術の発達により，現在では 単純写真から血管造影像に至るまで，ほぼ全ての放射 線画像のディジタル化が可能になってきている。しか ᄂ, CR (computed radiography)に代表される単純写真 のディジタル画像は，スクリーン・フィルム系のアナ ログ画像と同等もしくはそれ以下の画像情報しか現在 の技術では与え得ないので, ディジタル画像を単に表 示するだけでは，画像診断を行う放射線科医にとっ て，ディジタル技術の導入によって診断が容易になっ たとは思われない.したがって，単純写真のディジ夕 ル画像を診断にとって真に役立つものにするために は，本シンポジウムの他演者が述べているような高度 な画像処理技術および，画像の伝送および蓄積を迅速 に行うPACSなどの開発が重要である。さらに，画像 情報の定量化(計測) 㧍よび解析 (理解)を行い，その結 果を“第 2 の意見”として画像診断へ積極的に利用しよ うとするコンピュー夕支援診断 (computer-aided diagnosis; CAD) システム1 4)の開発は, ディジ夕ル画 像の特徴を最大限に利用した技術として不可欠である と考える。

\section{Sympesing \\ 桂川茂彦 岩手医科大学医用工学室}

$\mathrm{CAD}$ の一般的アプローチは次の 2 つに大別される. 一つは, 胸部単純写真にお打る結節状陰影の検出に見 られるように，異常陰影のありそうな箇所をコンピュ 一タが検出して表示し，見落としが起こらないように 注意を喚起する．他の一つは，心胸郭比の計測のよう に, 病巣についての定量的尺度を求めて, 読影の際に 客観的情報として提供することである。したがって， コンピュータの分析結果を画像診断に用いることで, 見落としによる䛊診を減少させ，また，主観的判断に よる思い違いを防止することができれば，画像診断の 正確度の向上と，再現性の改善が期待される。このよ うに，CADの目的はコンピュータが放射線科医の役 割を置き換えることではなく，放射線科医の読影がや りやすくなるように援助することにある。したがっ て, CADの基本的思想と方針は, 従来から自動診断 と呼ばれていたものとは根本的に異なるものであるこ とに注意する必要がある。

放射線画像情報の定量化の試みは，1970年代から炭 鉱夫塵肺症の重症度を自動分類する研究が数多くなさ れてきた5,6). 最近では，デジタルラジオグラフィお よび画像処理技術の急速な発展に伴い, CADの分野 